\title{
Zdeněk Nejedlý's Adoration of Fibich as Motive for His Attacks on Dvořák
}

\section{David R. Beveridge}

During the time of the "Battles over Dvořák" before World War I, Zdeněk Nejedlý-leader of the anti-Dvořák camp-made a pronouncement on the composer that has become infamous: "He is a boulder the young Czech musician must roll out of the way to be able to continue onward." ${ }^{1}$ Several years later Hugo Boettinger created his well-known caricature where the "boulder" is an enormous cliff. Nejedlý points to it and orders his disciples, armed with large, sharp pens: "Roll this boulder out of the way for me."

In our own time, during the past several decades, musicologists and historians have devoted extensive attention to Nejedlýs harsh pronouncements about Dvořák. Rudolf Pečman even made this issue the topic of a whole book. ${ }^{3}$ All agree that Nejedly's assessments were wrong or at least exaggerated. About the motivations for them, however, there is no strong consensus. Undoubtedly

1 Zdeněk Nejedlý, “Boj” proti Ant. Dvořákovi” [The "Fight” against Antonín Dvořák], Česká kultura 1, no. 6 (20 December 1912), 186-88, here 188: "Jest to balvan, jejž si mladý český hudebník musí odvalit z cesty, aby mohl dále.“

2 “Tento balvan mi odvalíte $\mathrm{z}$ cesty, [...].” Shaded India ink drawing, 1918. Held by the Czech Museum of Music, part of the National Museum in Prague, NM-ČMH 4, Acquisition no. 85/2000.

3 Rudolf Pečman, Útok na Antonina Dvoráka [Attack on Antonín Dvořák] (Brno: Filozofická fakulta Masarykovy univerzity, 1992). See also e.g. Marta Ottlová and Milan Pospíšil, "Konce ideje české národní hudby" [Endpoints of the Idea of Czech National Music], in Cechy a Evropa v kulture 19. století, ed. Petr Čornej and Roman Prahl (Prague: Národní galerie v Praze and Ústav pro českou literaturu ČSAV, 1993), 81-86; Marta Ottlová and Milan Pospíšil, "Motive der tschechischen Dvořák-Kritik am Anfang des 20. Jahrhunderts," in Dvořák-Studien, ed. Klaus Döge and Peter Jost (Mainz: B. Schott's Söhne, 1994), 211-16; Marta Ottlová, “The ‘Dvořák Battles’ in Bohemia: Czech Criticism of Antonín Dvořák, 1911-15," in Rethinking Dvořák: Views from Five Countries, ed. David R. Beveridge (Oxford: Clarendon Press, 1996), 125-33; Jindra Bártová, "Podivnosti kritických soudů v českém hudebním časopisectví na počátku stoletî” [Oddities of Critical Assessments in Czech Musical Periodicals of the Early Twentieth Century], Opus musicum 31, no. 4 (1999), 9-23; Milan Pospíšil, "Nejedlého kritika Dvořáka - operního skladatele” [Nejedlýs Critique of Dvořák as an Opera Composer], Opus musicum 32, no. 6 (2000), 13-20, and Vlasta Reittererová, "V hudbě život Ćechů 4" [In Music the Life of Czechs, Part 4], Harmonie 12, no. 4 (April 2004), 24-29, esp. 26-29. Most recently, Nejedlýs attitudes towards Dvořák receive extensive discussion in Jiří Křestan, Zdeněk Nejedlý: politik a vědec v osamèní [Zdeněk Nejedlý: Politician and Scholar in Isolation] (Prague and Litomyšl: Paseka, 2012), esp. 39-44, 57-58, 65-66, 83-90, and 114-15. 
important was the fact that, although Nejedlý respected Dvořák as a composer of absolute instrumental music, according to him absolute music could not be progressive, and he considered what was not progressive to be unimportant. In these as in other respects Nejedlý was strongly influenced by his teacher Otakar Hostinský, but applied Hostinskýs ideas much more strictly and ruthlessly. Certainly a role was played by Nejedlýs sense of injustice that Dvořák won greater fame during his lifetime than Smetana, mainly abroad. And then there is the anecdote about how Nejedlý had a romantic interest in Dvořák's daughter Otilie and was rudely rejected by the composer; this anecdote lacks any documentation and I consider its authenticity improbable, though it cannot be ruled out completely. ${ }^{4}$

Surprisingly, however, to my knowledge no study devoted to the battles over Dvořák has identified clearly a reason for Nejedlýs position that was certainly the original cause and probably the main one. Perhaps distracted by the fact that the unofficial organ for the anti-Dvořák camp in the battles over Dvořák was Nejedly's journal titled Smetana, founded in 1910, and by the traditional labelling of the warring camps as "Smetanians" and "Dvořákians", scholars have failed to draw sufficient attention to the fact that Nejedlýs attitudes against Dvořák originated not from an attempt to defend the reputation of Smetana, but from his truly passionate campaign to champion another composer, one with whom he had a very close personal relationship, namely his teacher Zdeněk Fibich. Not that Fibich himself had an inclination to denigrate Dvořák; all indications

4 The earliest evidence I know of the existence of this story is a letter of 7 January 1961 written by the composer's son Otakar Dvořák to Nejedlý, saying tourists who came to visit the composer's home in Vysoká near Pŕíbram often asked whether it was true Nejedlý had tried to win the hand of Otilie. Otakar said he himself doubted the story, that he knew about all relations his four sisters had with young men, and in Otilie's case was aware of none other than with Josef Suk. But he asked Nejedlý for a statement so that he could lay the matter to rest. We know not whether Nejedlý replied; if so, his answer is missing. See Křestan (op. cit., note 3), 58, referring to the original of Otakar's letter in the Nejedlý collection of Prague's Masaryk Institute and Archives of the Czech Academy of Sciences, inventory no. 463.

In Otakar's book about his father, completed in August 1961 a month before his death, he said nothing at all about Nejedlý. The passages about Nejedlý in the book's publication as Mijjotec Antonin Dvoŕák [My Father Antonín Dvořák] (Příbram: Knihovna Jana Drdy, 2004) are inserted by the editor Jan Koupil.

Apart from the said anecdote we have no evidence of Nejedlý ever having come into personal contact with or corresponded with Dvořák or any member of his family. If he indeed approached Otilie in some way, she cannot have offered him any hope: by the time he moved from Litomyšl to Prague in the autumn of 1896 her romantic relationship with Suk was already well established though they were not yet formally betrothed. Perhaps Nejedlý approached her father in the matter without having even spoken to the object of his desire, having only admired her from afar. More likely, however, this anecdote arose as a mere hypothesis, in an uninformed attempt to explain Nejedlýs extraordinary long-term aversion to both Dvořák and Suk. 
are that the two composers were sincere friends with a high degree of mutual respect for each other's achievements. ${ }^{5}$ But Nejedlý himself denigrated Dvořák out of a desire to elevate the relative position of Fibich.

In order to recognize this, first let us move back in time from Nejedlýs pronouncement in 1912 about the "boulder." Already eleven years earlier, at the age of twenty-three, he issued his first blistering attack on Dvořák, in this case focused on a single work, in his review of the opera Rusalka following its première on 31 March $1901 .^{6}$ Reacting to highly laudatory reviews published earlier, Nejedlý thoroughly damned the work, calling it "a series of musical ideas without dramatic connection," and a work that is "in its overall intention erroneous, bad." Another priceless pronouncement: "Rusalka's leitmotiv [...] appears every time

5 See David R. Beveridge, "Fibich and Dvořák: The Hidden Friendship between Two 'Enemies', in Zdenék Fibich as a Central European Composer at the End of the Nineteenth Century, ed. Patrick F. Devine, Vladislava Kopecká, and Jiří Kopecký (Olomouc: Universitas Palackiana Olomucensis, 2010), 287-96. Jindra Bártová gives a perhaps misleading impression in "Podivnosti kritických soudů v českém hudebním časopisectví na počátku století,” op. cit. (note 3), 11, when she groups Fibich together with Otakar Hostinský as teachers of Nejedlý whose "authority he fully respected." "Zdeněk Nejedlý plně uctíval autoritu svých učitelů, jimž určoval ve svém systému hodnot význačná místa.") It is clear that he indeed respected greatly the opinions of Hostinský, but if he adopted any specific opinions from Fibich he never said so, at least not in his publications.

6 The only known previous occasions when he said anything at all about Dvořák were:

- In 1895 when, at the age of seventeen, he gave a talk about Smetana to students and teachers of the gymnasium in his native Litomyšl and compared him favourably to both Dvořák and Fibich. See Křestan, op. cit. (note 3), 29. We have no details.

- In the first two instalments of his article "Zdenko Fibich," Obzor literárni a umélecký 2, nos. 16, 17, and 18 (9 November, 30 November, 18 December 1900), [241]-244, 257-61, and 278-281, where he says in several passages that in various respects Fibich was superior to both Smetana and Dvořák.

- In the third instalment of the said article, 280: "Fibich byl přiliš hluboký, aby viděl českost $\mathrm{v}$ tanečním rhytmu (jak činí národní škola ruská a u nás v některých skladbách Dvořák a jeho škola)"; [...] [Fibich was too deep to see Czechness in dance rhythm (as is done by the Russian national school, and in our country by Dvořák and his school in some pieces.)]

- And 281: “Dvořák je symfonik, ale pravou zpěvohru již nikdy nenapíše.”[Dvořák is a symphonist, but will never write a true opera.]

- In “Mistr Zdeněk Fibich 1850-1900,” Hlas národa, 21 December 1900: “[...] že Dvořák narodil se již 1841, v první polovici století, k níž svým talentem i mistrovstvím plně se hlásí." [Dvořák was born already in 1841, in the first half of the century, to which with his talent and mastery he fully belongs.] And: "Po smrti Dvořákově také stěží nalezneme důstojného nástupce jeho v hudbě absolutní." [And after the death of Dvořák we shall scarcely be able to find a worthy successor in absolute music.]

7 Zdeněk Nejedlý, "Dvořákova 'Rusalka'," Rozhledy: Týdenník pro politiku, védu, literaturu a umèní11, no. 8 (25 May 1901), 205-09, here 205: “Rusalka' jest řada hudebních myšlenek bez dramatické souvislosti.” And 207: “Rusalka' není hudebním dramatem, jako jím nebyly dřívejší opery Dvořákovy. Protože však nemůžeme připustit jiný útvar zpěvohry než hudební drama, jest 'Rusalka' již v celkové intenci dílo chybné, špatné." 
the composer thought about Rusalka and never changes [...].” ${ }^{8}$ Never changes? Let us examine just a tiny selection from the many dozens of forms in which this motive appears over the course of the opera: ${ }^{9}$

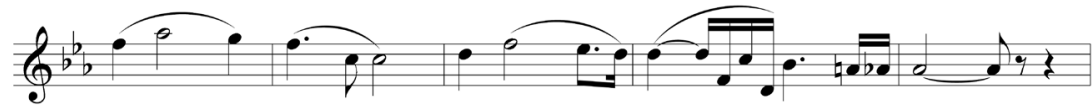

Example 1: Orchestra, just before Rusalka's first words [“Hastrmánku! tatíčku!”]

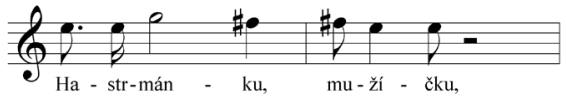

Example 2: Sung by Rusalka later in her first dialogue with the Vodník [Water Goblin]
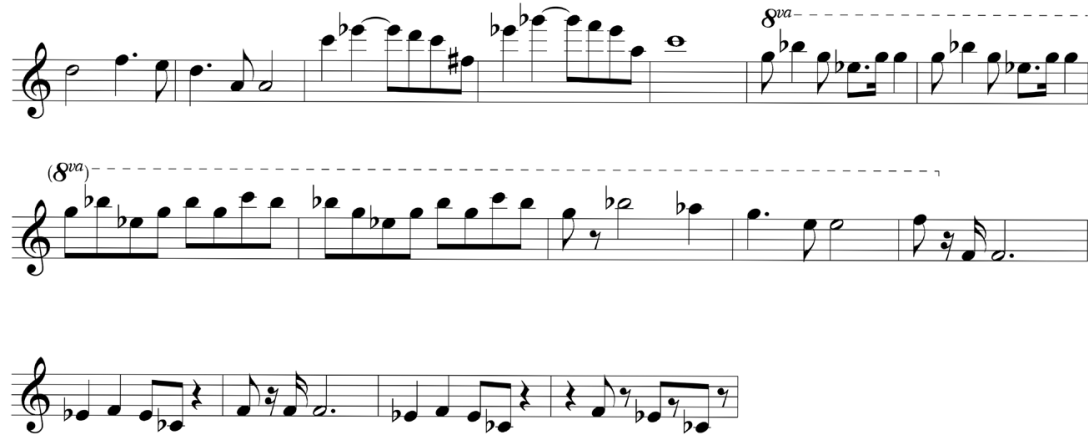

Example 3: Orchestra, still in Act I, in the witch's hut, preparation for Rusalka's transformation into a human

8 Ibid., 205: "Příznačný motiv Rusalčin [...] vyskytá se všude, kde si skladatel na Rusalku vzpomněl a nemění se nikde $[\ldots]$. ."

9 Nejedlý probably noticed three points in the opera where Rusalka's motive is indeed almost identical-in Act I before her first words (our Example 1), and in Act III before her words "Vyrvána životu...", then before her final appearance addressing the Prince, "Miláčku, znáš mě, znáš?”-as well as, perhaps, its rather similar occurrence before her song to the moon in Act I, "Měsíčku na nebi hlubokém..."- and failed to notice or chose to ignore the myriad further appearances in forms that are changed very substantially yet still clearly recognizable. 


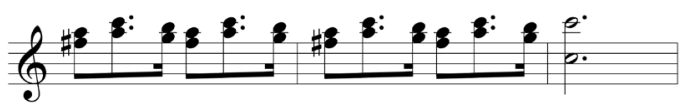

Example 4: Orchestra, in Act II just before Rusalka, frantic, cries out to her father "Vodníčku, tatičku drahý!"

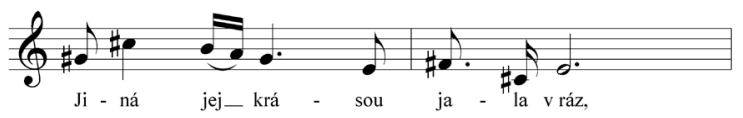

Example 5: Several pages later, sung by Rusalka.

One could give further examples of Nejedly's assertions about this opera that are objectively false, as well as examples of his opinions with which almost nobody agreed at that time, and today perhaps even less so.

Why was Nejedlý so set against Rusalka? Why was he as though deaf to its many virtues and why did he write such nonsense about this work?

Crucial is the temporal context: Nejedlý was very much under the impression of an event that had occurred less than half a year before the première of Rusalka, a sad event on 15 October 1900 important in the history of Czech music, but having for Nejedlý importance that was absolutely overwhelming. It was the premature death of Fibich, not yet fifty years old, with whom Nejedlý had studied composition for four years, a composer whom he almost literally worshipped both as an artist and as a human being, a composer who in his opinion-note well-was underappreciated.

Decades later Nejedlý recalled what Zdeněk Fibich had meant to him and the impact of his death:

When in the autumn of 1896 [...] I came to Prague to pursue my studies, my first steps [...] took me to Zdenko Fibich, to arrange for composition lessons [...]. Apparently already at that time I was attracted to him [...] by his moral and cultural relation to art, in which he differed strikingly from his milieu in the $1890 \mathrm{~s}^{10}$

${ }_{10}$ Zdeněk Nejedlý, Zdenka Fibicha milostný deník: Nálady, dojmy a upominky [Zdeněk Fibich's Amorous Diary: Moods, Impressions, and Remembrances] (Prague: Hudební matice Umělecké besedy, 1925), 9: "Když jsem na podzim r. 1896 [...] prrišel na studie do Prahy, byla první má cesta [...] ke Zdenkovi Fibichovi, abych si smluvil hodiny komposice [...]. Patrně mne již tehdy k němu táhl [...] jeho mravní a kulturní poměr k umění, jímž se Fibich nápadně lišil od svého okolí let 90 tých.” 
So: Fibich's milieu lacked a proper moral and cultural relation to art. One wonders whom Nejedlý had in mind as representatives of that milieu. Certainly prominent among those representatives was Dvořák. But let us continue directly with Nejedlýs recollection:

\begin{abstract}
All the way out to the countryside, to that remote corner of Bohemia [Litomyšl], had wafted from Fibich's whole image a spirit of pure, selfless devotion that had ravished me already as a boy in Smetana and other Czech people, but which at that time, after Smetana's death, when our musicians and the whole milieu of the time had succumbed more and more to a totally utilitarian concept of their life's task, was ever more rare. And so the path to Fibich was for me above all a path to one of the last living sources of this spirit in our country. [...] I certainly learned a lot from him, and his music afforded me experiences of indescribable beauty and depth, but dearest to me above all this was always his person, full of that pure magic. [...] Still today I remember what a powerful effect my very first lesson had on me. [...] The impression was so powerful that afterward I ran along the embankment for several hours, until that which Fibich had suddenly aroused in me calmed down at least a little. And that's the way it continued to be, for the whole four years that I went to visit him.

How strong all of this was in me is most clear from the fact that perhaps nothing determined my future work in Czech music so much as the death of Fibich. ${ }^{11}$
\end{abstract}

Indeed. Less than a month after Fibich's death Nejedlý began publishing a substantial article in instalments describing and assessing his achievements. ${ }^{12}$ This article then became the beginning of his very first book, published in mid1901 (hard on the heels of his damning review of Rusalka), namely Zdenko

${ }^{11}$ Ibid., 9-10: "Až tam na venkov, do vzdáleného koutu Čech, vanul ke mně z celého Fibichova zjevu duch čisté, nezištné oddanosti, jenž mne uchvacoval již jako hocha na Smetanovi i jiných českých lidech, jenž však tehdy, po smrti Smetanově, kdy naši hudebníci stejně jako celé tehdejší prostředí propadávali čím dále tím více docela utilitárnímu pojetí životního úkolu, byl stále vzácněǰši a vzácnější. A tak cesta $\mathrm{k}$ Fibichovi byla mi především cestou za jedním $\mathrm{z}$ posledních ještě zdrojů tohoto ducha u nás. [...] Naučil jsem se od něho jistě mnoho a z jeho hudby dostalo se mi zážitků přímo nepopsatelné krásy a hloubky, ale nad to vše mi vždy nejdražší byla Fibichova osobnost, plná tohoto čistého kouzla. [...] Ještě dnes vzpomínám, jak na mne působila hned první hodina. [...] Dojem na mne byl tak mocný, že jsem potom proběhal po nábřeží několik hodin, než se ve mně aspoň poněkud uklidnilo, co ve mně tehdy Fibich naráz rozbouřil. A tak tomu bylo i dále, po celá ta čtyři léta, jež jsem k Fibichovi docházel. Jak to vše pak bylo ve mně silné, patrno zajisté nejlépe z toho, že nic snad o mém budoucím působení v české hudbě nerozhodlo tolik jako Fibichova smrt."

12 Zdeněk Nejedlý, "Zdenko Fibich," Obzor literárni a umélecký 2, nos. 16, 17, and 18 (9 November, 30 November, 18 December 1900), [241]-244, 257-61, and 278-281. The third instalment is headed "Konec první části” [End of Part I], but there is no continuation in this or any other journal, only in the book (see below, note 13). 
Fibich: Founder of Staged Melodrama. ${ }^{13}$ The first three paragraphs of the article, however, are not found in the book and are very revealling. In them we read that: "He [Fibich] had been seriously ill for a whole week, but no report reached the public until Friday, and so in that moment Prague had no idea that within its walls the foremost living dramatic composer of the world was dying." ${ }^{14}$ Note: "the foremost living dramatic composer of the world." Nejedlý continues: "[M]odest was his burial, without the pomp of the splendid funerals of Meyerbeer, Wagner, or Smetana. [...]"15 Actually from extensive period reports on Fibich's funeral in the daily press we know that it was a magnificent event with participation by perhaps all the important organizations and prominent figures of Prague in the field of music, as well as extensive representation of broader artistic spheres and politics. ${ }^{16}$ Crushed by the loss of his beloved teacher, Nejedlý perhaps did not register everything that was happening, or if so, it did not seem to him sufficient. Continuing our quotation from Nejedlýs article: "The pain from Fibich's death is still too strong for me to be able to approach his works immediately with cool scientific analysis. By this I explain, also in what follows, some words that are perhaps too ardent." 17

Strange that Nejedlý acknowledges some of his assertions will be exaggerated or at least highly debatable - and nevertheless publishes them! For example, still in the article's first instalment: "Fibich's musical technique is immensely refined,

13 Zdeněk Nejedlý, Zdenko Fibich: Zakladatel scénického melodramatu (Prague: Nákladem vlastním [= at the author's own expense], Tiskem B. Outraty v Jičíně [printed by B. Outrata in Jičín], 1901). Concerning the date of publication within the year 1901, see the book's p. 180 reporting the death of Betty Fibichová on 20 May 1901 and a "Dodatek" (Addendum) at the very end, on p. 188, stating that after the book was printed an article on Fibich by Hostinský had been published on 8 June 1891. On p. 256 in Rozbledy 11, no. 10 (8 June 1901) Nejedlý referred to the book saying "již v blízké době vyjde" [it will be published very soon]. And from Křestan (op. cit., note 3), p. 59 we know that as of 6 July 1901 Nejedlýs future wife Marie Brychtová had just purchased the book.

Probably in 1903 (certainly no sooner) the book was reprinted, essentially unchanged, by Hejda \& Tuček, with support from Section IV of the Czech Academy for Sciences, Literature, and Art (whose foremost member in music was Dvořák!).

${ }^{14}$ Zdeněk Nejedlý, “Zdenko Fibich,” Obzor literárni a umélecký 2, no. 16 (9 November 1900), [241]: "Stonal těžce celý týden, do veřejnosti však nepronikla ani zpráva, až v pondělí, a tak se stalo, že Praha v jmenovanou chvíli ani netušila, že v jejích zdech umírá nejpřednější dnešní dramatický skladatel světa."

${ }^{15}$ Ibid.: "Stejně skromně byl pohřben, bez pompy nádherných pohřbů Meyerbeerova, Wagnerova neb Smetanova. [...]"

16 "Pohřeb Zdeňka Fibicha" [The Funeral of Zdeněk Fibich], Národni listy 40, no. 288 (18 October 1900), [morning edition], 2, cols. [1-3], and "Pohřeb mistra Zdeňka Fibicha," Národní politika 18, no. 288 (18 October 1900), [morning edition], [3-4].

17 Zdeněk Nejedlý, “Zdenko Fibich,” Obzor literárni a umélecký 2, no. 16 (9 November 1900), [241]: "Bolest nad smrtí Fibichovou je př́liš ještě živá, abych dovedl přistoupit hned $\mathrm{k}$ jeho dílům s chladem vědecké analyse. Tím vysvětluji i v dalším některá snad př́liš vřelá slova.” 
artistic, and splendid such that in this matter he certainly excels both Smetana and Dvořák." 18 And in the second: "Especially his harmony decidedly surpasses both Smetana and Dvořák. [...] Polyphony is a characteristic feature of Fibich's works, in which he excels not only Smetana and Dvořák but the greatest modern masters, not excepting even Wagner himself." ${ }^{19}$ After describing Fibich's procedure of following the opening movement of his Symphony in E flat major directly with an Adagio in the remote key of B major, Nejedlý exclaims: "This could be done only by the progressive spirit of Fibich; in vain would we seek any earlier analogy." ${ }^{20}$ In this case, however, Nejedlý apparently realized his error; in the book version he removed this sentence. ${ }^{21}$ As also in the case of the following claim about Fibich's opera Boure [The Tempest]: "The voice-leading in the choruses in these passages has scarcely any rival in literature worldwide, but such a use of fugue is in itself unique in the nineteenth century." ${ }^{22}$ On the other hand at one point in the book Nejedlý would insert a bold claim not present in the corresponding passage of the article: "Fibich must be called the most melodic Czech composer. The brilliantly-inspired melodic contours of Pád Arkuna [The Fall of Arkun] place him alongside the greatest master of melody to date, Wagner." ${ }^{3}$

But let us return to the introduction to the original article, where Nejedlý continues:

It is impossible to undo now what happened before his death. [That is, to take back the pain that Fibich suffered from being undervalued.] It belongs to history, just as does what happened to Smetana. Prof. Hostinský in his speech over

18 Zdeněk Nejedlý, “Zdenko Fibich,” Obzor literární a umèlecký 2, no. 16 (9 November 1900), 243 (6 in the book—see note 13): "Fibichova hudební technika je nesmírně raffinovaná, umělá a nádherná tak, že v té věci předstihuje jistě Smetanu i Dvořáka.”

19 Obzor literární a umélecký 2, no. 17 (30 November 1900), [257] (8 in the book-see note 13): “Zvláště jeho enharmonika rozhodně převyšuje Smetanovu i Dvořákovu." And 258 (11 in the book): "Polyfonie je charakteristická vlastnost Fibichova tvoření, jí pak staví se nejen nad Smetanu a Dvořáka, nýbrž i nad největší mistry moderní, ani samého Wagnera nevyjímaje. [...]"

20 Obzor literární a umélecký 2, no. 17 (30 November 1900), 258: "To dovedl jen pokrokový duch Fibichův, před tím marně bychom hledali analogie toho."

${ }^{21}$ In the book-see note 13 - this discussion is on p. 9.

22 Obzor literárni a umélecký 2, no. 17 (30 November 1900), 259: "Vedení hlasů ve sborech na těchto místech hledá si soupeře v celé světové literatuře, avšak takové užití fugy je vůbec unikem XIX. století." This pertains to Act I-to the wandering of the unfortunate sailors, lured astray by Ariel, through the forest.

${ }^{23}$ Zdeněk Nejedlý, Zdenko Fibich: Zakladatel scénického melodramatu (op. cit., note 13), 20: "Fibicha nutno nazvat nejmelodičtějším českým skladatelem. Geniální melodické kontury "Pádu Arkuna" staví ho po bok největšímu dosud mistru melodie, Wagnerovi." This is inserted into the discussion of Fibich's melody originally published in the third instalment of the article, Obzor literárni a umélecký 2, no. 18 (18 December 1900), 280. 
Fibich's grave referred well to these injustices. If Smetana was a martyr to progress, Fibich was as well. ${ }^{24}$

What Hostinský had said was: "Unfortunately, however, the natural fate of men of progress is that that they earn every scrap of recognition with hard work, sometimes with a tough struggle." 25

And who among Czech composers then living gained such recognition apparently - at the time- without a tough struggle? Dvořák. This is obvious especially in the case of his reception abroad and reports on that reception in the Czech press. Undoubtedly Nejedlý was irritated by the unbelievably extensive reports in Czech periodicals on Dvořák's triumphs in England starting in 1884-reports that sometimes even exaggerated those triumphs a bit. ${ }^{26}$ Then came reports on his trip to Russia in 1890 which, influenced by the desire of fervent Czech patriots to see support for their endeavours in a fellow Slavic nation, portrayed as a clear victory critical response that in reality was quite disappointing. For instance: "Maestro Dvořák scored real triumphs with his works in both main cities of Russia, making famous not only his own name but also Czech musical art and winning complete, universal, and most flattering recognition." ${ }^{27}$ It would take many decades for readers outside Russia to learn the truth about Russian critical

${ }^{24}$ Zdeněk Nejedlý, “Zdenko Fibich,” Obzor literární a umélecký 2, no. 16 (9 November 1900), [241]: "Odčinit to, co se dělo před jeho smrtí, po jeho smrti již se nedá. To náleží historii stejně tak jako to, co se dělo Smetanovi. Prof. Hostinský ve své řeči nad hrobem Fibichovým dobře ukázal na tato protivenství. Byl-li Smetana mučedníkem pokroku, Fibich byl jím též."

25 Národní politika 18, no. 288 (18 October 1900), [morning edition], [3-4], here [4], col. [1]: "Žel však, že přirozeným údělem mužů pokroku jest: vydobývati si každou píd’ uznání pernou prací, ba druhdy i tuhým zápasem."

${ }^{26}$ By reprinting mainly the most favourable passages from British reviews, in Czech translations that are sometimes imprecise, tending to make the reviews sound even more favourable than they were. Dvořák's trips to England had been in March and September 1884, April-May and August 1885, October-November 1886, April 1890, June 1891, October 1891, and March 1896.

27 Národní listy 30, no. 87 (29 March 1890), [afternoon edition], [2-3], beginning: "Mistr Dvořák slavil svými skladbami v obou metropolách Rusi pravé triumfy. Proslavil tam nejen své vlastní jméno, nýbrž i také české umění hudební a zjednal si úplné, všeobecné a nejlichotivější uznání. [...]”

This unsigned article is probably by Gustav Eim, a regular contributor to Národní listy, and appears to be based entirely on a letter Dvořák wrote to Eim [on 23 March 1890]; see Antonin Dvořák: Correspondence and Documents, ed. Milan Kuna et al., Vol. 3 (Prague: Editio Supraphon, 1989), 32-33. But the article omits Dvořák's complaints about the Russians in that letter and exaggerates what he said about his successes.

In Dalibor 12, no. 15 (22 March 1890), 118, col. [1] we find a reprint (without acknowledgement) of an unsigned article in the Olomouc newspaper Našinec (Olomouc) 26, no. 30 (12 March 1890), [3], col. [1] purporting to describe the enormous and unmitigated success Dvořák scored with his concert in Moscow on 7 March (by the Western calendar), saying e.g. that both composer and violinist were loudly cheered after the performance of the Violin Concerto. This is pure fiction: the writer obviously had not attended the concert and knew nothing about how it had turned out. 
response to Dvořák's concerts there. ${ }^{28}$ But Nejedlý may have discovered the real state of affairs during his sojourn in Russia in the summer of $1900 .^{29}$

Concerning Dvořák's spectacular successes in America, mainly with the first performances of his Ninth Symphony ("From the New World"), F major String Quartet, and E flat major String Quintet in 1893 and 1894, period reports in the Czech press were relatively restrained. But let us move ahead now to 1900, the year of Fibich's death, when we find further proclamations of Dvořák's glory that no doubt irritated Nejedlý. In March that year the philharmonic orchestra of Berlin devoted a whole concert to works by Dvořák (conducted by Oskar Nedbal in Dvořák's absence), in connection with which we read in the leading Czech music journal Dalibor that Dvořák was "after Smetana the most brilliant star of the Czech musical Parnassus [...]." ${ }^{30}$ And for example that: "All over Germany today the name Dvořák is sounding with the pure resonance of a great contemporary musical genius." ${ }^{11}$ Then in March 1901, just before the première of Rusalka, the Czech press brought reports of the great success of Dvoŕák's Requiem in Vienna (again in Dvořák's absence), including quotations from the Vienna press which however omit what was negative. ${ }^{32}$

It had been postponed from 7 to 11 March, and the Violin Concerto had been removed from the programme because the soloist had fallen ill.

28 The full content of Dvořák's letter to Eim (see note 27) would not be published until 30 September 1932, in the afternoon edition of Prague's Lidové noviny 40, no. 495, 2, then in the first edition of Otakar Šourek's Dvorák ve vzpominkách a dopisech [Dvořák in Letters and Reminiscences] (Prague: Topic, 1938), 82-83. (In the last, ninth edition of that book [Prague: Národní hudební vydavatelství, 1951], and its only English edition, as Antonín Dvořák: Letters and Reminiscences, trans. Roberta Finlayson Samsour [Prague: Státní nakladatelství krásné literatury, hudby a umění, 1954], 127-28, three passages in this letter complaining about the Russians are deleted.) For honest accounts of response by the Russian press to Dvořák's concerts in Moscow and St. Petersburg, readers outside Russia had to wait for an article by John Clapham, "Dvořák's Visit to Russia," The Musical Quarterly 54, no. 3 (July 1965), 493-506 and one by Milan Kuna, "Dvořák a Rusko," Hudebni rozhledy 30, no. 2 (1977), 386-97, reprinted with revisions in his book Dvoŕákovské variace: studie a stati [Dvořák Variations: Studies and Essays] (Prague: LaMartre, 2019), 35-61. The said article by Clapham contains what is to this day the only complete English translation of Dvořák's letter to Eim.

${ }^{29}$ For information about that sojourn see Křestan, op. cit. (note 3), 48.

${ }^{30}$ V. Nejdl, "Před koncertem" [Before the Concert], Dalibor: Hudebni listy 22, no. 9 (3 March 1900), 66-69, here 67: "po Smetanovi nejskvělejší hvězda skladatelská českého hudebního Parnassu [...].”

31 V. Nejdl, "Berlínské vítězství," Dalibor: Hudební listy 22, no. 10 (10 March 1900), [73]-74, here 74: "Po celém Německu zaznívá dnes jméno Dvořák ryzím zvukem velikého současného hudebního genia."

32 See Národní listy 41, no. 62 (3 March 1901), 4, col. [4] and Dalibor: Hudební listy 23, no. 10 (9 March 1901), 82. Viennese periodicals reviewing the concert included Illustriertes Wiener Extrablatt and Neue Freie Presse of 5 March, Neues Wiener Journal and Ostdeutsche Rundschau of 7 March, Das Vaterland and Deutsche Kunst- und Musik-Zeitung of 10 March, and Neues Wiener 
In his book about Fibich Nejedlý felt the need to interpret Dvořák's successes, in particular his successes abroad, not as evidence of the quality of his music, but rather - paradoxically — as the very opposite:

Dvořák's music, much simpler than that of Smetana and Fibich, is more accessible to the broader concert audience, consisting mostly of enthusiastic amateurs most accustomed to post-Beethovenian absolute music. Therefore it naturally has greater success than the progressive programmatic works of Smetana and Fibich. In Vienna they even defeated Smetana and Fibich with Dvořák. Smetana and Fibich were not admitted through the gates to Viennese concerts, whereas Dvořák, supported by conservative elements, scored great successes there. Dvořák's success in unmusical England is also interesting in this respect. A modern artist could not have made such a mark there as Dvořák did. ${ }^{33}$

Elsewhere in his book Nejedlý reveals his inclination to badmouth Dvořák for the sake of adulating Fibich in a most peculiar way. He illustrates Fibich's "dramatičnost" [dramatic character] not be giving some admirable example; rather, what he gives is an example of what he considers gross violation of dramatic character in a work by Dvorák -in one passage from his universally-celebrated cantata The Spectre's Bride - an example of an alleged dramatic error that Fibich would allegedly never have committed. ${ }^{34}$ Then he declares his position quite openly, still in his book on Fibich, when he writes: "Criticism [...] stands either behind Smetana and thus Fibich, or on the side of Dvořák." 35

This makes clear to us the motivation, or at least a large part of the motivation, for Nejedlýs many criticisms of Dvořák in his book on Fibich, and his even more offensive verdicts that followed two years later in The History of Czech Music, for instance: "A progressive artist demolishes the old form and creates

Tagblatt of 13 March. All these reviews are indeed favourable to very favourable on the whole, but most of them also express moderate to serious reservations.

${ }^{33}$ Zdeněk Nejedlý, Zdenko Fibich: Zakladatel scénickébo melodramatu (op. cit., note 13), 174: "Hudba Dvořákova, mnohem jednodušší než Smetanova a Fibichova, jest přístupnější i širšímu obecenstvu koncertnímu, jež sestává většinou z náruživých dilettantů, zvyklých nejvíce absolutní hudbě pobeethovenské, proto přirozeně zjednává si více úspěchů než pokrokové programní skladby Smetanovy a Fibichovy. Ve Vídni dokonce Dvořákem poráželi Smetanu a Fibicha. Tito dva nebyli vpuštěni do bran vídeňských koncertů, kdežto Dvořák, nesen konservativními živly, slavil tu veliké úspěchy. Úspěch Dvořákův v nehudební Anglii je též po této stránce zajímavý. Moderní umělec nemohl by tam tak proniknout, jako Dvořák pronikl."

${ }^{34}$ Ibid., 77-78.

35 Ibid., 174: "Kritika [...] staví se bud" na stranu Smetanovu a s tím i Fibichovu nebo na stranu Dvoŕákovu.” 
a new one; Dvořák lacks the artistic intelligence to create new forms." ${ }^{36}$ Nejedlý felt that Fibich was underappreciated, and sensed this as a serious injustice. Most conspicuous among Fibich's colleagues who were not underappreciated was Dvořák. And in order to elevate the relative position of his hero, Nejedlý resorted to denigrating the achievement of his chief "rival." ${ }^{37}$

Unfortunately, as it turned out Nejedlýs exaggerated glorification of Fibich at the expense of Dvořák harmed his hero more than it helped him. ${ }^{38}$ If Fibich was unjustly neglected in favour of Dvorák at that time, today this is the case even much more so. Nevertheless we can learn something from Nejedlýs writings about these two composers. Without having any need to follow him in denigrating Dvořák, we can recognize the legitimacy of his conviction that Fibich, too, was a brilliant composer and that he deserves greater attention.

\section{Zdeněk Nejedlý's Adoration of Fibich as Motive for His Attacks on Dvořák}

\section{Abstract}

During recent decades historians and musicologists have devoted major attention to the harsh judgments of Zdeněk Nejedlý regarding Antonín Dvořák, devoting even one whole book to this topic. They have engaged in speculations about the causes of these judgments in the aesthetic, social, and political context of the time. It seems, however, that one of these causes, evidently the original cause and perhaps the main cause, has not yet been identified as such. To recognize it we must be aware that although Nejedlýs best-known condemnations of Dvořák come from the time of the "Battles over Dvoŕák" that broke out in 1912, his positions in this matter were essentially fully developed already much earlier, at the very beginning of his career. For example, in 1903 he wrote: "Dvořák lacked the artistic intelligence to create new forms." Critical is the fact that Nejedlý denigrated Dvořák even earlier, in his book about Zdeněk Fibich published in 1901, where many passages surprise us with assertions that in harmony, in subtle

36 Zdeněk Nejedlý, Dějiny české hudby (Prague: Hejda \& Tuček, [1903]), 206: "Pokrokový umělec rozbije starou formu a vytvoří novou, Dvořákovi nedostávalo se intelligence umělecké k vytvoření nových forem."

37 In 1907, six years after publishing his Fibich book, Nejedlý gave a series of lectures on Smetana's operas in which for the first time his principal motivation for attacks on Dvořák became defense of that elder composer. These lectures were then published as the book Zpervohry Smetanovy [The Operas of Smetana] (Prague: J. Otto, 1908), in which we find for example on pp. 259-60 the outrageous assertion that none of Dvořák's chamber works possesses the "vital, enthralling power" (životní síly a úchvatnosti) found in both of Smetana's string quartets.

38 As aptly observed by Křestan, op. cit. (note 3), 40. 
rhythms, in polyphony, in melody, in "musical technique," and in orchestration, inferior to Fibich was not only Dvořák but also the composer best known as Nejedlýs hero: Smetana. Nejedlý had published part of this book in advance in instalments in a periodical, late in 1900 shortly after Fibich's death, with an introduction that makes even clearer his adoration of this composer not only as an artist (with whom he himself had studied composition) but as a human being, and his bitter conviction that Fibich had not received the recognition he deserved. Later in the book he attempts to explain Dvořák's greater career success by the assertion that his music is "much simpler" and that England, which conferred such glory on him, was an "unmusical" country. From these observations and others we may conclude that Nejedlý felt the need to criticize Dvořák as the one who had received recognition that rightly belonged to Fibich. And in part Nejedlý was correct: even if we perhaps think Dvořák was a greater composer, it is indisputable that at the end of the nineteenth century his fame unjustly left Fibich in the shadow-which today is even more the case than then.

\section{Nejedlého láska k Fibichovi jako příčina odmítnutí Dvořáka}

\section{Abstrakt}

$\mathrm{V}$ posledních desetiletích věnovali historikové a hudební vědci velkou pozornost odmítavým názorům Zdeňka Nejedlého na Antonína Dvořáka; tématem se dokonce zabývala celá jedna monografie. Př́činy těchto vyjádření se nejčastěji hledají v tehdejších estetických, sociálních a politických poměrech. Zdá se však, že jedna z nich, dokonce snad původní a možná i hlavní, nebyla dosud identifikována jako taková. Abychom ji poznali, musíme si uvědomit, že ačkoli Nejedlého nejznámější protidvořákovské výroky pocházejí z doby tzv. „bojů o Dvořáka“, které vypukly v r. 1912, jeho postoje $v$ této věci se v zásadě plně utvořily už mnohem dřive, na samém počátku jeho kariéry. Např. v roce 1903 napsal: „Dvořákovi se nedostávalo inteligence umělecké k vytvoření nových forem." Klíčové je zjištění, že Nejedlý odsuzoval Dvořáka již ve své knize o Zdeňku Fibichovi, kde nás mnohá místa př́kvapí tím, že např. v harmonii, jemné rytmice, polyfonii, melodii, „hudební technice“ a instrumentaci údajně Fibicha nedostihl nejen Dvořák, ale ani nejznámější Nejedlého hrdina, totiž Smetana. Část této knihy vydal Nejedlý časopisecky koncem r. 1900, tedy krátce po Fibichově smrti. Z jejího úvodu jasně vyplývá, jak tohoto skladatele zbožňoval, a to nejen jako umělce (u nějž sám kdysi studoval kompozici), ale i jako člověka, a jak se trápil při pomyšlení na jeho nedoceněnost. $V$ knize samotné se pokouší vysvětlit Dvořákưv úspěch tím, že jeho hudba je „mnohem jednoduši“ a že Anglie, která jej tak proslavila, je „nehudební“ zemí. Z těchto i dalších poznatků můžeme usoudit, že Nejedlý 
cítil potřebu kritizovat Dvořáka jako toho, jemuž se neprávem dostalo slávy po zásluze náležející Fibichovi. Nejedlý měl částečně pravdu: byt̉ jsme sami přesvědčeni, že Dvořák byl větším skladatelem, je nesporné, že koncem 19. století jeho sláva už Fibichovu výrazně a ne zcela zaslouženě převyšovala, což dnes platí ještě v daleko větší míře.

\section{Keywords}

Zdeněk Nejedlý; Antonín Dvořák; Zdeněk Fibich; Battles over Dvořák

\section{Klíčová slova}

Zdeněk Nejedlý; Antonín Dvořák; Zdeněk Fibich; boje o Dvořáka

David R. Beveridge

davbeve@gmail.com 